\title{
AN ANALYSIS ON THE EC COMMISSION'S PROGRESS REPORTS REGARDING TO THE FREEDOM OF EXPRESSION AND TURKEY'S ACCESSION TO THE EU
}

Kerem BATIR*

\begin{abstract}
:
The aim of this study is to evaluate Turkey's reform process within the framework of $E U$ accession negotiations with a major focus on freedom of expression. It is argued that EU membership has become a major incentive for Turkish reforms and this includes legislative changes with regard to freedom of expression as well. The extent that Turkey has succeeded to adopt political and social rights generally shared within the EU is analyzed in this study by examining EU progress reports along with official documents on Turkey's progress in reform implementation. A brief overview of cases will serve to a better understanding of the improvements in freedom of expression. The study ends by concluding that EU has become an external force for Turkish political reforms and those changes have become more obvious especially since the opening up of accession negotiations in 2005.
\end{abstract}

Keywords: Human Rights, Freedom of Expression, Accession Process, Progress Reports.

$\ddot{O}_{z e t:}$

Bu çalışmanın amacı Türkiye'nin AB Katılım Müzakereleri çerçevesinde Turkiye'nin reform sürecini ifade özgürlüğünü odak noktası olarak alarak değerlendirmektir. AB üyeliğinin Türkiye'nin gerçekleştirdiği reformlar için önemli bir saik haline geldiği ve özellikle ifade özgürlüğü konusundaki yasal değişikliklerin de bu kapsamda yapıldı̆̆ı iddia edilmektedir. Türkiye'nin reformları uygulamadaki başarısı konusunda diğer resmi

\footnotetext{
* Assist. Prof. Dr., Çanakkale Onsekiz Mart University, Biga Faculty of Economics and Administrative Sciences, Department of International Relations.
} 
belgeler yanında $A B$ ilerleme raporların inceleyerek Türkiye'nin genel olarak $A B$ tarafindan paylaşılan siyasi ve sosyal haklarin kabulünde hangi ölçüde başarıll olduğunu incelenmeye çalışılmıştır. Bazı davalar hakkında genel bilgiler vermek ifade özgürlüğ̈̈ konusundaki gelişmelerin daha iyi anlaşılmasına yardımcı olacağı da düşünülmü̈ştür. Çalışma AB'nin Türk Siyasi reformları için dısssal bir güç haline geldiği ve bu değişikliklerin 2005 yılında müzakerelerin açılmasından bu yana daha göze çarpmakta olduğu sonucuna varmaktadir.

Anahtar Kelimeler: Insan Haklarl, Ifade Özgürlüğü, Katılım Süreci, Ilerleme Raporlarl

\section{Introduction}

The founding treaties of the European Communities (EC) did not make any explicit references to human rights especially to the freedom of expression. This results primarily from the fact that the central motivation of the EC was economic, rather than political. The aim of the founding members was to establish a common market by eliminating all kinds of physical, technical and fiscal barriers to trade, facilitating the free flow of capital and labor, and establishing an economic and monetary union. To that end, the key strategy used to foster the process of economic integration was to harmonize divergent economic policies of the EU member states. This meant changing national legislations concerning socioeconomic issues by a number of EU regulations, directives and decisions (Cini, 2003).

However, since then, the economic integration within Europe has achieved a much higher degree than was conceivable in the 1950's. The harmonization of economic policies and the pooling out sovereignty to different levels of governance have had a significant impact on citizens which created, in turn, the need for considering social and political aspects of integration as well. As a result, human rights have become important topics of the EU agenda. This includes sustainability of democratic institutions, ensuring equality, the rule of law, social justice and guaranteeing human rights. It is safe to argue that over the years the EU has succeeded in creating certain political and social standards shared by all member states.

Meanwhile, Human Rights have become foreign policy tools of the European Union. Especially since the Copenhagen Summit in 1993 the European Union has set conditions for countries aspiring for the EU membership. As regards political conditions, candidate countries are 
expected to fully ensure individual rights such as human rights, protection of minorities, democratic governance, freedom of expression and freedom of association in order to join the EU. The same standards apply to Turkey which has been a candidate of the EU since 1999 Helsinki Summit. After the granting of an official candidate status in 1999, Turkey initiated a reform process whereby a number of legislative amendments were made to comply with the European principle (Kubicek, 2005; Gunter, 2007).

Progress reports (referred to originally as Progress Reports and later as Regular Reports) are the instruments used by EC Commission in order to analyze annually whether, with respect to Copenhagen Criteria, reforms had been implemented. The first progress reports were released in 1998 after the beginning of official negotiations with Central and Eastern Europe Countries. For Turkey the first Progress Report was released in 1998, even before the announcement of her official candidacy. The accession negotiations of Turkey were started seven years after the first progress report.

\section{Freedom of Expression}

Freedom of expression is a keystone of democratic rights and freedoms in a democratic society. It is one of the basic conditions for society's progress and for the development of every person. The right to freedom of expression upholds the rights of all to express their views and opinions freely. In European level the Freedom of expression is secured by the Article 10 of the European Convention on Human Rights. The Convention states that:

'Everyone has the right to freedom of expression. This right shall include freedom to hold opinions and to receive and impart information and ideas without interference by public authority and regardless of frontiers. This article shall not prevent States from requiring the licensing of broadcasting, television or cinema enterprises.

The freedom of expression can be restricted by individual governments in some extraordinary situations if this kind of restriction has already been prescribed by law and is crucial in a society governed by democratic principles. Article 10 of the Convention continues that:

The exercise of these freedoms, since it carries with it duties and responsibilities, may be subject to such formalities, conditions, restrictions or penalties as are prescribed by law and are necessary in a democratic society, in the interests of national security, territorial integrity or public safety, for the prevention of 
disorder or crime, for the protection of health or morals, for the protection of the reputation or the rights of others, for preventing the disclosure of information received in confidence, or for maintaining the authority and impartiality of the judiciary.

The European Court of Human Rights (ECHR) has often recalled that freedom of expression constitutes one of the most essential foundations of a democratic society and basic conditions for individuals' self-fulfilment. It is an essentiall right which should be promoted and protected to a maximum extent given its critical role in democracy and public participation in political life. So the protection of this right is crucial for the society and as European Court of Human Rights stated " every "formality", "condition", "restriction" or "penalty" imposed in this sphere must be proportionate to the legitimate aim pursued" (ECHR Handyside Judgment, 1976)

At early stages, the freedom of expression was deemed to guarantee effective political and social debate essential for the proper operation of any democratic system. However the freedom of expression has evolved into a more individual freedom that permits individuals to freely communicate between each other to send or receive information. So the freedom of expression extends beyond the political dimension and covers areas like science, literature, theather, the arts, and even pornography.

\section{Freedom of Expression in the European Union (EU)}

The founding treaties did not consist of any explicit reference to human rights and freedom of expression was never mentioned. Nevertheless, with the Single European Act (1987), the European Community made a significant move towards the enhancement of the fundamental rights of the Community citizens. The EC states declare in the preamble that:

Members are determined to work together to promote the democracy on the basis of the fundamental rights recognized in the constitutions and laws of the Member States, in the Convention for the Protection of Human Rights and fundamental rights and the European Social Charter'

In the field of external relations, the Community points to its commitment to fundamental norms and values set out by the United Nations and declares that it will respect and these principles in its relations with third countries. The EC members state that they are:

(...) aware of the responsibility incumbent upon Europe to aim at speaking ever increasingly with one voice and to act with consistent solidarity in order to more effectively protect its common interests and independence, in particular to display the 
principles of democracy and in compliance with the law and with human rights to which they are attached so that together they make their own contributions to the preservation of international peace and security, in accordance with the undertaking entered into by them within the framework of the United Nations Charter'

In 1991, the EC member states signed the Treaty on the European Union (TEU) agreed on the establishment of the European Union. With the TEU, the EU drew attention to the: 'the importance of systems of government founded on principles of democracy, respect for fundamental rights, protection of human rights and fundamental freedoms.' Later with the Amsterdam Treaty, the EU members amended this article and stated that ECHR would become the fundamental source of the Union's human rights principles. Article 6 amended by the Amsterdam Treaty states that:

'1. The Union is founded on the principles of liberty, democracy, respect for human rights and fundamental freedoms, and the rule of law, principles which are common to the Member States.

2. The Union shall respect fundamental rights, as guaranteed by the European Convention for the Protection of Human Rights and Fundamental Freedoms signed in Rome on 4 November 1950 and as they result from the constitutional traditions common to the Member States, as general principles of Community law (...)'

As the EU growed in numbers of the Member States, the Union payed much more attention to the Human Rights. First, the provisions regarding to human rights wer inserted into EU Constitution. After the failure of the ratification process the efforts were focused to a new treaty. By Lisbon treaty the above metioned Article 6 was amended and now it states that:

1. The Union recognises the rights, freedoms and principles set out in the Charter of Fundamental Rights of the European Union of 7 December 2000, as adapted at Strasbourg, on 12 December 2007, which shall have the same legal value as the Treaties.

The provisions of the Charter shall not extend in any way the competences of the Union as defined in the Treaties.

The rights, freedoms and principles in the Charter shall be interpreted in accordance with the general provisions in Title VII of the Charter governing its interpretation and application and with due regard to the explanations referred to in the Charter, that set out the sources of those provisions. 
2. The Union shall accede to the European Convention for the Protection of Human Rights and Fundamental Freedoms. Such accession shall not affect the Union's competences as defined in the Treaties.

3. Fundamental rights, as guaranteed by the European Convention for the Protection of Human Rights and Fundamental Freedoms and as they result from the constitutional traditions common to the Member States, shall constitute general principles of the Union's law.

Lisbon treaty is a major step for protection of human rights inside the Union. The Charter of Fundamental Rights lists political, social, and economic rights for EU citizens. Under the provisions quoted herein above, the Charter is legally binding (except for those member states with an optout for this provision i.e. the United Kingdom and Poland). The Charter is intended to make sure that, EU legislations should not contradict the European Convention on Human Rights which is ratified by all EU Member States and now, to which the EU as a whole has acceded under the Treaty of Lisbon. Article 6 of the Treaty on European Union elevated the Charter to the same legal value as the Treaty on European Union and the Treaty on the Functioning of the European Union.

Besides, there are other legal sources of the EU's human rights other than the Community Law. For instance, throughout the European integration, decisions made by the European Court of Justice (ECJ) have become important reference points for the enhancement of the legal foundation of human rights in the EU. In many instances, the ECJ has pointed out that legislation of individual member states along with the international treaties that member states have ratified form the basis of the EU's human rights policies. Particularly important is the European Convention on Human Rights and the various articles related to fundamental freedom of individuals. In many cases, the ECJ have made references to the rights guaranteed by the European Convention on Human Rights and decisions were taken accordingly.

For example in Bernard Connolly vs. Commission ${ }^{1}$ the ECJ found an infringement of freedom of expression and ruled in reference to article 10 of ECHR. In this case, Mr. Connolly is dismissed from his post at the Commission on the grounds that he published a book criticizing in a harsh

\footnotetext{
' Connolly v. Commission, C-274/99, Judgment of the Court of 6 March 2001, available at http://eurlex.europa.eu/LexUriServ/LexUriServ.do?uri=CELEX:61999J0274:EN:HTML
} 
way the policies of the economic and monetary integration. Although he obtained the documents used during the writing process without having asked for the permission of the institutions, the ECJ decided on the infringement of the freedom of expression which it identified as one of basic freedoms of a democratic society. ECJ stated that:

"Fundamental rights form an integral part of the general principles of law, whose observance the Court ensures. For that purpose, the Court draws inspiration from the constitutional traditions common to the Member States and from the guidelines supplied by international treaties for the protection of human rights on which the Member States have collaborated or to which they are signatories. The European Convention for the Protection of Human Rights has special significance in that respect. Those principles have been restated in Article 6(2) of the Treaty on European Union."

The EU has a separate judiciary body, however for the cases regarding to human rights issues the EU and her court ECJ strictly bound themselves to the Council of Europe's Convention and her court ECHR.

\section{EU Accession and Freedom of Expression in Turkey}

The EU has played a significant role in initiating political changes on a continent that had for centuries characterized by violent clashes and wars. This includes both economic development and harmonization of divergent political and social policies to foster integration. The improvements achieved since the beginning of the European integartion are noteworthy. Over the years Europeans have made important steps so that human rights including the freedom of expression are fully respected by all member states. The same applies to candidate countries waiting for EU accession. The main instrument used by the EU to stimulate political change in candidate countries is its conditionality meaning that EU offers membership (carrot) on the condition that the candidate country fully respects the same political standards shared by the member states. If the candidate country follows the path, accession is finalized (Schimmelfennig, Engert and Knobel, 2003).

Consequently, the EU has become an important catalyst for political change in candidate countries. The same is true for Turkey which is since 1999 Helsinki Summit an official candidate aspiring to become a full member of the EU. During Helsinki, the EU declared that in order to start with accession negotiations, Turkey has to fulfil some conditions that are applicable for all countries wishing to join the EU: 
'Building on the existing European strategy, Turkey, like other candidate States, will benefit from a pre-accession strategy to stimulate and support its reforms. This will include enhanced political dialogue, with emphasis on progressing towards fulfilling the political criteria for accessionwith particular reference to the issue of human rights (Presidency Conclusions, Helsinki European Council, 10-11 December 1999).'

Since then, Turkey has initiated a reform process in order to comply with the criteria set by the EU at the Copenhagen Summit of 1993. This process intensified during and after the initiation of accession negotiations in 2005 . The reform package includes both economic and political reforms including provisions related to the freedom of expression (Baç, 2005). As noted above, the freedom of expression is one of the essential elements of a pluralist liberal democratic society; therefore legislative changes in this area constitute a significant part of Turkey's accession negotiations. In Turkey, freedom of expression is guaranteed by both domestic laws and international treaties. Since the start of legislative amendments on 3 October 2001, freedom of expression in Turkey was regulated by the Article 26 issued of the 1982 Constitution. Article 26 states that:

"Everyone has the right to express and disseminate his thought and opinion by speech, in writing or in pictures or through other media, individually or collectively. This right includes the freedom to receive and impart information and ideas without interference from official authorities. This provision does not preclude subjecting transmission by radio, television, cinema, and similar means to a system of licensing. The exercise of these freedoms may be restricted for the purposes of preventing crime, punishing offenders, withholding information duly classified as a State Secret, protecting the reputation and rights and the private and family life of others, or protecting professional secrets as prescribed by law, or ensuring the proper functioning of the judiciary.

No language prohibited by law may be used in the expression and dissemination of thought. Any written or printed documents, phonograph records, magnetic or video tapes, and other means of expression used in contravention of this provision shall be seized by a duly issued decision of judge or, in cases where delay is deemed prejudicial, by the competent authority designated by law. The authority issuing the seizure order shall notify the competent judge of its decision within twenty-four hours. The judge shall decide on the matter within three days.

Provisions regulating the use of means of disseminating information and ideas shall not be interpreted as a restriction of the 
freedom of expression and dissemination unless they prevent the dissemination of information and thoughts" (unofficial translation by Erhan Yaşar).

Hakyemez and Akgün (2002) argue that because the aim of the 1982 Constitution was to defend the Republic against individuals and groups, it reflected some authoritarian elements putting restrictions on individual freedoms. Article 13 states that:

Fundamental rights and freedoms may be restricted by law, in conformity with the letter and spirit of the Constitution, with the aim of safeguarding the indivisible integrity of the State with its territory and nation, national sovereignty, the Republic, national security, public order, general peace, the public interest, public morals and public health, and also for specific reasons set forth in the relevant articles of the Constitution ... The general grounds for restriction set forth in this article shall apply for all fundamental rights and freedoms (cited in Hakyemez and Akgün, 2002).

During the 1980's and 1990's, prosecutors as well as judges put restrictions on the freedom of expression on the basis of Article 13. When interpreting cases brought under Article 26, fundamental rights were restricted in order to protect the state from individuals that could constitute a danger to the Republic. However with the initiation of reforms in October 2001 a number changes were made relating to the fundamental freedoms. This included the extention of the scope of social and economic rights such as personal liberty and security, freedom of association, secrecy of communications, freedom of residence and freedom, the right to work, the right to form labour unions and the right to an equitable wage. In total 34 Articles were amended including Article 13. With the amendment, the general grounds for restrictions on fundamental rights were deleted. The new Article 13 states that:

"Fundamental rights and liberties may be restricted only by law and solely on the basis of the reasons stated in the relevant articles of the constitution without impinging upon their essence. These restrictions shall not conflict with the letter and the spirit of the Constitution, the requirements of democratic social order and the secular Republic, and the principle of proportionality" (cited in Özbudun, 2007).

The 2001 amendments brought changes to Article 26 as well. With the 2001 amendment, the wording language prohibited by law' was removed from the text. Likewise, as regards Article 176, Grand National Assembly replaced the phrase 'thoughts and opinions' by the word 'activity'. The amended Article 176 reads as follows: "(N)o protection shall be afforded to 
thoughts and opinions contrary to Turkish national interests, the indivisibility of the State with its territory and nation, Turkish historical and moral values; Atatürk's nationalism, his principles, reforms, and modernism."

A significant improvent was the amendement of Article 90 of the Constitution of the Turkish Republic in 2004 which states that with the ratification of international treaties by the Turkish Grand National Assembly, international legislation takes precedence over Turkish domestic law. Turkish courts have so far made a number of decisions referring in an explicit way to specific provisions of treaties and protocols signed within the framework of the European Convention on Human Rights. Meanwhile, Turkey makes several legal amendments, including the abolishment of certain provisions such as the death penalty, in order to become eligible for EU membership. ${ }^{2}$ Since the opening up of negotiations with the EU in 2005 , Turkey has initiated a comprehensive reform process, whereby a wide range of laws related to fundamental freedoms and human rights have been amended.

\section{An Examination of Freedom of Expression in EC Progress Reports on Turkey}

Turkey's success to comply with the Copenhagen criteria is examined by EU institutions and accordingly the European Commission prepares Progress Reports indicating the development in areas including political and social rights. The Commission has so far issued ten annual reports on Turkey's progress in reforms. These reports are based on information provided by Turkish authorities, the European Parliament, Council of Europe, international organizations and various non-governmental organizations (EC Commission, 1998).

In its Regular Report on Turkey's Progress towards EU Accession issued in 1998, the European Commission pointed to several problems with regard to freedom of expression and criticized Turkey by noting that:

(...) freedom of expression is not fully assured in Turkey. An excessively narrow interpretation of the Constitution and

\footnotetext{
${ }^{2}$ For a complete analysis of the changes in the form of legislative reform packages please read Ercüment Tezcan, "Türkiye'nin Kopenhag Siyasi Kriterlerine Uyumu Sürecinde Yapılan ve Yapılması Gereken Yasal Değişiklikler Üzerine Bir Değerlendirme" (An Analysis on the Legal Changes Enacted in the Turkey's Harmonization Process to the Copenhagen Political Criterion) Marmara Journal of European Studies, Vol:11, No:1-2, 2003:59-96.
} 
other legal provisions (Articles 7 and 8 of the Anti-Terror

Law, Articles 158, 159, 311 and 312 of the Criminal Code) concerning the unity of the state, territorial integrity, secularism and respect for formal institutions of the state is regularly used to charge and sentence elected politicians, journalists, writers, trade unionists or NGO workers for statements, public speeches, published articles or books that would be acceptable in EU Member States'

In its 1999 Progress Report the Commission refered to the worsening of the freedom of expression in Turkey especially after the capture of Abdullah Ocalan during the same year. Special attention is paid to communiqué issued by the Minister of Justice that urges Turkish Governors to identify individuals, associations, foundations, piblications and organisations that tend to behave in favour of Ocalan. In this changing political scene in Turkey, sentences related to the abuse of freedom of expression were raised. A significant step was made as President Suleyman Demirel agreed on a law that ensivaged the postponement of prosecutions and punishments for offences made via press and broadcasting. With this law, sentences can be postponed for a three-year period and if persons in question commit the same offence during three years, the original sentence is to be applied. However, the Commission criticizes the situation of journalists who are already in prison for having been charged with belonging to an illegal organization. Cases mentioned in the report are that of Akin Birdal and the NGO TOSAV that was charged with having made speratist propaganda. During 1999, the European Court of Human Rights ruled in eleven cases that Turkey had infringed the freedom of expression ensured by the ECHR. This included cases concerning the freedom of press which, in the eyes of the European Commission, has shown no real progress (EC Commission, 1999).

The 2000 Progress Report was less than promising. Besides reiterating the various cases that violated the freedom of expression in Turkey, the Commission noted that Turkish courts particularly restrict the freedom of expression regarding views about the situation of the Kurdish people. Calling on Turkey to find long-lasting solutions to end further infringements, the Commission urged Turkish courts to respect the ECHR and restrict the freedom of expression only in situtions causing violence. Regarding the Turkish media, the European Commission paid particular attention to the High Board of Radio and Television (RTÜK). The progress report criticized the suspension of the broadcasting activities of various television and radio stations by RTÜK and urged Turkey to improve the situation through legal amendments (EC Commission, 2000). 
In its report in 2001, the Commsision criticized the widespread usage of the Article 159 of the Penal Code in restrictions on the freedom of expression. This encompasses mainly insults to the Turkish Parliament, Turkish Army, the Turkish Republic and the Turkish judiciary. Moreover, the Commission called for the amendment of Article 312 used to charge individuals for inciment to racial, ethnic and religious hostilities. Particular attention was paid to various cases where judges restrict the freedom of speech by referring to Article 7 and 8 of the anti-terrorist law (disseminating separatist propaganda). Constitutional amendments particularly with regard to Articles 13 and 14 as well as Articles 22, 26 and 28 are appreciated while noting that further changes were necessary to fully ensure the scope of freedom of expression. The Commission welcomed the the decisions on the abolishment of provisions that prohibited the use of languages other than Turkish. Another important development was the abolishment of the provising that had long prohibited the publications made in certain languages (EC Commission, 2001).

Meanwhile, the European Commission pointed to the high number of infringements of the freedom of expression in Turkey. One important case in this regard was the prosecution of sixteen journalists for the re-production of articles in a book on freedom of thought. Also, the Commission expressed its concern about the imprisonment of eighty journalists in 2001 for political moves or alleged violation of Turkish laws. These include charges of insulting the judiciary and the Republic; as well as of disseminating separatist propaganda and portraying the Republic in a 'state of weakness.' The Commission stated that though legislative changes are promising, more legal amendments are necessary. It also urged Turkish courts to implement the newly adopted legislation in concrete cases and guarantee the respect for the freedom of press. As for the situation of broadcasting, the report pointed to a law adopted by the Turkish Parliament in 2001 which forsaw the nomination to the High Audio-Visual Board of a member by the National Security Council. The Commission made it clear that the practice of such legislation contradict EU standars and would highly restrict the freedom of expression in Turkey.

In 2002, the Commission progress report on the situation of the freedom of expression in Turkey is very rich in scope. Turkey's adoption of three reform packages was highly appreciated by the European Commission. Particular emphasis was paid to the amendment of various articles to ensure the full implementation of the freedom of expression in Turkey. This includes amendment of Article 159 (insults to the State and to State insitutitons and views threatening the indivisibile unity of the Turkish 
Republic) which decreased prsion sentences from six to three years imprisonment. This amendment also removed fines imposed on individuals expressing critical views about Turkish laws. With the amendment of Article 159, individuals criticizing Turkish institutions would no long be charged unless their aim is to 'insult' or 'deride' them. The Commission also welcomed the amendment of dthe escription of Article 312 (incitement to hatred on the basis of differences of social class, race, religion, sect or region). With the newly revised description, only activities that constitute a threat to the public order would be subject to charges. Moreover, the report pointed a number of improvements regarding the reduction of prison sentences for offences in general and the shortening of bans on television and radiobroadcasting (EC Commission, 2002).

However, the Commission declared its dissatisfaction with the result achieved in reality. While appreciating legislative developments in the form of both reform packages and specific provision amendments, the Commission observed an inconsistency between legal changes and the implementation in concrete cases. For instance, specific emphasis has been placed on the tendency to use articles (other than the amended ones) of the Constitution to bring cases with regard to the freedom of expression. An example is the frequent usage of Article 169 of the Turkish Penal Code (support of illegal organizations) which was commonly used by judges in 2002. The Commission criticized the banning of several books and periodicals as well as cenure on films on the ground of incitement to state institutions. $^{3}$

With regard to the freedom of the press and broadcasting, the progress report of 2002 welcomed legal amendments and reform packages adopted to improve freedom of expression in Turkey ${ }^{4}$. However, the Commission

${ }^{3}$ According to a report published by the Association of Turkish Editors on 25 May 2002, 40 books were banned or subject to investigation in the first half of 2002 alone. In the same years, a film called Big Man, Small Love, was banned on the grounds that the depiction of police brutality in the film offended police officers.

${ }^{4}$ In the area of freedom of press, the first reform package amended Article 8 of the Anti-Terror law increasing fines imposed on publishers charged with making terrorist propaganda. The second reform package reduced the maximum suspension of publishing companies as well as the maximum length of imprisonment for the ones who continue to publish during suspension periods. The third reform package chaged the Press Law replacing prison stences with heavy fines. As regards freedom of broadcasting, the first reform package reduced the maximum closure period for radio and TV channels found guily of making propaganda against the 
pointed out that despite significant changes legislative changes, the Turkish Press Law still constitutes a significant obstacle towards the ensurement of freedom of press and dissemination of thought. In this regard, the progress report criticized the widespread use of Articles 7 and 8 of the Anti-Terror Law and Articles 159 and 169 of the Turkish Penal Code to put restrictions on members of press corporations. The Commission demonstrated its dissatisfaction with the censorship intrduced by RTÜK on freedom of expression. This includes restrictions on the Internet content and charges in the use of 'offensive language, libel, obscenity, incitement to separatism, or for the broadcasting of programmes in Kurdish.,

The 2003 Progress Report contained several encouraging views as regards developments in the area of freedom of expression in Turkey. The Commission welcomed the abolishment of various restrictions as well as the release of prisioners found guilty for opinions that were considered as nonviolent. Among the positive developments in 2003 was the abolishment of the Article 8 of the Anti-Terror Law (propaganda against the indivisible unity of the state) within the framework of the sixth reform package. The Commission stated that the reduction of the minimum sentence under Article 159 of the Penal Code (insulting the state and state institutions and threats to the indivisible unity of the Turkish Republic) from one year to six months was an important step towards the ensurment of the freedom of speech. Thanks to this amendment, expression of views aimed to criticize and not aimed to 'insult' or 'deride' state institutions were no longer charged with prison sentences or fines. Another significant improvement was the narrowing of the scope of Article 169 of the Penal Code (aiding and abetting terrorist organizations) through repealing the provison that had often used to sanction 'actions which facilitated the operation of terrorist organisations in any manner whatsoever.' Likewise, the seventh package amended Article 7 of the Anti-Terror Law by putting 'resorting to violence or other terrorist means' instead of using 'terorist methods' as a cause for charging individuals for making propadanda of a terrorist oganization. Accordingly, prison sentences for such crimes remained the same wheras

indivisibile unity of the Turkish Republic to seven days instead of fifteen days. The third reform package amended the RTÜK law enabling broadcasting in languages other than Turkish as well as different dialects used by Turkish citizens. The amendment points out that broadcasts are subject to restrictions if activities threaten the unity of the State.

${ }^{5}$ Examples of censorship by RTÜK include closure of CNN Türk for a day in April 2002 and Gün TV for the whole year. 
fines were increased. As regards broadcasting, the 2003 progress report welcomed efforts to eliminate previous actions aimed at banning and suspending works. With the sixth reform package, only works considered to 'undermine the fundamental principles of the Republic the indivisible integrity of the state' were covered by the legislation. (EC Commission, 2003)

The Commission welcomed these developments considering them as significant movements towards the strengthening of the freedom of expression in Turkey. Yet, it also pointed to the need for further legal amendments. It also drew attention to the existing gap between legislative changes and daily practice. The Commision expressed its concern about the tendency among Turkish prosecutors to rely on alternative provisions to restrict the freedom of expression including Articles 312 and 169 of the Penal Code and the Article 7 of the Anti-Terror Law. The progress report also urged judges and prosecutors to make consistent interpretations and implementation of the legislation improved in the reform process. As regards the freedom of press, the Commission expressed an explicit concern about the slow pace of reforms. ${ }^{6}$

At the same time, the progress report criticized the failure of the Turkish Authorities to implement legislative changes in concrete cases. Here, the Commission obsevered a lack of consistency between reform adoption and reform implementation. It criticized heavy penalties and imprisonement of several journalists, authors and publishers found guily for expressing critical views about state institutions and policies as well as elimination of publications and technical equipments and censorship on publishing houses and the internet. The Commission also emphasized the expectation from Turkey to put reforms allowing the use of other languages other than Turkish into practice. ${ }^{7}$

\footnotetext{
${ }^{6}$ In 2003, Turkey made a number of legislative amendments related to the freedom of press. For instance, the fourth reform package introduced a provision preventing authoritites to force periodicals, editors and writers to explain theie sources. The seventh reform package amended Law 765 and excluded scientific and artistic works from the scope of the relevant legal provisions that had long prohibited publications based on moral arguments.

In 2002, Turkey introduced an amendment opening up a possibility to broadcast in languages and dialects used by Turkish citizens in their daily lives. Yet, this kind of broadcasting could only be done in TRT (the public broadcaster of Turkey). In the 2003 Turkey adopted a new legislation within the sixth reform package allowing private stations, in addition to TRT to broadcast in languages other than
} 
The 2004 progress report on Turkey's reform process within the framework of EU accession welcomes the diminishing number of prosecutions and convictions in cases relating to the freedom of expression. Amendments to the Ant-Terror Law and the Press Law were appreciated as well as the beginning of broadcasting in laguages and dialects used by Turkish citizens in their daily lives. Special emphasis was paid to the reducing number of cases as regards Articles 159 (insulting the state and the state institutions) 169 (adding and abetting terrorist organizations) and 312 of the Penal Code (incitement to racial, ethnic or religious enmity) as well as Article 7 of the Anti-Terror Law (propaganda in connection with the (terrorist) organisation in a way that encourages the resort to violence or other terrorist means). A significant development in 2004 was the acquittal of all persons convicted under the amended Article 8 of the Anti-Terror Law (propaganda against the indivisible unity of the state and the shortening of prison sentences with the changes made to Articler $159 .{ }^{8}$ The 2004 progress report also welcomed the tendency in judgements to make references to Artcile 10 of the ECHR and the acquittals made accordingly describing it a significant move towards the ensurement of freedom of expression (EC Commission, 2004).

With regard to the freedom of press, the Commission declared its satisfaction with the degree of progress made by legal amendments. For instance, it was decided that Article 30 would no longer be used for the seizure of printing equipments of publishers found guilty for their expressions. An important step was the adoption of the new Press Law in June 2004 which strengthened the right of journalists not to reveal their sources and reinforced the right to reply and correction. Further improvement made with the Press Law was the replacement of prison sentences with fines and the removal of sanctions in the form of closing publications, stopping their distribution and seizure of publishing equipment. The Commission also welcomed the first broadcasts in Bosnian,

Turkish. However, the progress report in 2003 states that despite these legislative developments, no broadcasts have so far been made in languages and dialects other than Turkish.

${ }^{8}$ The report mentions that the official figures indicated that as of April 2004, 204 persons were acquitted thanks to the legislative amendments made by the State Security Courts. As of May 2004, 5809 persons were detained for terrorism related crimes, an almost $35 \%$ decrease when compared to 2000,2001 , and an almost $10 \%$ decrease when compared to 2002 . 
Arabic, Circasian and the Kurdish dialects of Kirmançi and Zaza in June 2004.

As in previous cases, the progress report expressed critical opinions about the real implementation of legislative reforms. Prosecution and conviction of persons on the basis of amended articles of the Penal Code and Anti-Terror Law were stil widespread in 2004 and prosecuters still charged persons expressing non-violent opinions by relying on alternative provisions. This includes the revised Article 159 in cases where individuals make ciritical opinions about state institutions including religious staff criticizing the state and those expressing opinions leading to the discouragement of people from military service. The Commission urged Turkey to accelarate the reform process and make amendments so that Turkish legislation could be in accordance with Article 10 of the ECHR. It also asked Turkey to ensure the dircet effect of the ECHR and its judgements in the interpretation of domestic legislation. The progress report also criticized the heavy fines imposed on press corporations at both local and regional levels and the still widespread banning of publications. ${ }^{9}$

With the 2005 progress report on Turkey, the Commission welcomed reforms within the area of freedom of expression. Relying reports provided by Turkish Authorities and various NGO's as regards restrictions on freedom of expression, the Commission pointed to the diminishing number of cases and prosecutions and encouraged Turkey to make further amendments. It emphasized the importance of a number of amendments towards the reinforcement of freedom of expression in Turkey including the narrowing of the scope of Article 125 and the abolishment of Article 305 (offences against fundamental national interests). Likewise, the progress report points that publications related to Kurdish and Armenian issue were easier in 2005 than previous ages and as Turkish Publishers Association acknowledge authors and publishers found guilty for such offences were more likely to be released in the same year. The Commission also expressed its support for the positive developments achieved after the adoption of the new Press Law and the new Criminal Code. Based on figures provided by the Turkish Press Council in 2005, there were no journalists in prison because of the nature of their works (EC Commission, 2005).

${ }^{9}$ According to figures by the Turkish Publishers Association 18 books were banned in the first half of 2004 . In 2003 a total number of 43 books were banned and also 54 persons were found guilty for their opinions. 
On the other hand, the progress report expressed strong concern about the broad usage of Article 301 of the new Criminal Code, formerly Article 159 (insulting the State and State institutions). The Commission criticize that in 2004 this provision was frequnetly used to charge individuals for expression of their views. Article 301 encompasses the following:

“- A person who explicitly insults being a Turk, the Republic or Turkish Grand National Assembly, shall be imposed a penalty of imprisonment for a term of six months to three years.

- A person who explicitly insults the Government of the Republic of Turkey, the judicial bodies of the State, the military or security organisation shall be imposed a penalty of imprisonment for a term of six months to two years.

- Where insulting being a Turk is committed by a Turkish citizen in a foreign country, the penalty to be imposed shall be increased by one third.

- Expression of opinions with the purpose of criticism does not require penalties."

The provision attracted substatial criticism because of its widespread usage for prosecuting writers and journalists. The author was charged under Article 301 being found guilty for insulting Turkishness with his description of 1915 events as a massacre of Armenians. Likewise, the same article was used in a case taken against a well-known journalist Hrant Dink for insulting Turkish identity and he was sentenced to six-month imprisonement. In September 2005, Emin Karaca was charged under Article 301 for expressing critical views about the past activities of the Turkish military. His five month prision sentence was replaced by a fine. Ragip Zarakolu was also found guilty for publishing his opinions about the Kurdish and the Armenian topics. Considering all these cases, the Commission urges Turkey to bring cases only in situations leading to violence, rebellion or enmity among the public. It also encourages the interpretation of domestic legislation in accordance with Article 10 of the ECHR. As regards broadcasting, the progress report points to the limited progress achieved in 2005 and inadequate number of programs in languages and dialects other than Turkish. It also criticized the intervention of RTÜK in broadcasting through cancellation or suspension of programs.

The 2006 progress report starts with the welcoming of a circular issued by the Turkish Ministry of Justice calling on prosecutors to explicity refer to European Convention on Human Rights when interpreting cases in the area of freedom of expression. This circular also foresaw the monthly monitoring of criminal investigations and cases against the mass media. The progress 
report also pointed that the broadcasts in languages other than Turkish became easier than the years. Nevertheless, the Commission was still critical about the high number of cases brought against non-violnet expression of opinions. It paid special attention to the Article 301 which was widely used to prosecute journalists, writers, publishers, academics and human rights activists found gulity of insulting Turkishness, the Turkish Republic and its institutions although the intent was not to create violent actions that could constitute a threat to public order and security. This includes the confirmation of the six-month prison sentence for the journalist Hrant Dink for insulting Turkishness in his article on the Armenian identity. The Commission urged Turkish authorities to make necessary amendments to Article 301 so that legal provision would be in accordance with European standards. It also expressed its concern about the Anti-Terror Law and its usage against non-violent expressions. The Commission stated that the definition of the crimes in Anti-Terror Law were not in line with the Concil of Europe Convention for the Prevention of Terrorism and that : "(f)reedom of the press and media could be undermined by provisions allowing the suspension of periodicals and introducing the liability of chief editors and of press and media owners for publishing terrorist propaganda or praise in press or media organs." This includes the arrest and detention of Füsun Erdoğan (Özgür Radyo) and 22 other journalists; 5 from Atilim newspaper, 5 from Özgür Halk and Genç Bakış, 2 from Odak Newspaper and 10 other journalists (EC Commission, 2006).

However when compared to previous reports, the 2006 progress report was much more positive as regards the Commission's evaluation about improvements in the area of freedom of expression in Turkey. Though there was still criticism about the limited consistency between reforms and law implementation in daily practice, the Commission welcomed the dimishing number of cases as well as of the arrest and detention of journalists, writers and publishers for expression of individual opinions.

The 2007 progress report was very critical in nature although it points to a number of improvements related to the freedom of expression in Turkey. The Commission welcomed the open discussion of various topics which had previously been regarded as sensitive issues by the Turkish society. However, the report particularly emphasized the raising number of prosecutions under Article 301. Algan argues that Article 301 makes no contribution to the broadening of freedom of expression in Turkey. Because the replacement of the word 'Turkishness' by the term 'Turkish Nation' with the 2008 amendment created no changes in the content of the Article 301 , it is still too broad in scope and prosecuters could still use it to bring 
cases against persons expressing their views on a wide range of topics on Turkey. The same applies to lack of difference between the terms 'Republic' and 'the State of the Turkish Republic.' Here again, no significant change has been made to remove restrictions on freedom of expression. $^{10}$

It pointed to some cases that raised concerns about Turkey's compliance with European standards of freedom of expression. The suspension of publication of the weekly newspaper Nokta which published a wide range of articles on Turkish military is one example mentined in 2007 progress report on Turkey. Particulary important was the case brought against Professor Baskın Oran and Professor İbrahim Özden Kaboğlu who were charged with 'inciting hatred and hostility' in their discussion of 'citizenship in Turkey' in which they urged Turkey to recognize Kurds as a distinct minority. Their acquittal in May 2007 was a positive improvement towards the enchancement of freedom of expression in Turkey, though their acquittal was overturned by the Court of Appeal in September 2007 (EC Commission, 2007). In short, the Commission was not totally satisfied with Turkey's success in complying with European standards. However, when compared to previous years an examination of 2007 progress report illustrates the gradual progress achieved in reforms and their implementation in daily practice. Despite critical points, a new era opened in Turkey's reform process towards EU accession beginning with 2006 and 2007.

The 2008 progress report provides further evidence on Turkey's progress towards the strengthening of freedom of expression and the Commission's positive evaluations about a wide range of improvements.

In 2009, Commission's views about the freedom of expression in Turkey start with a positive development. The Commission noted that the amendment of Article 301 of the Turkish Criminal Code led a "significant decline" in prosecutions compared with the previous years. ${ }^{11}$ According to

${ }^{10}$ For a detailed analysis on Amendment of Article 301 and Freedom of Speech Cases in Turkey please read, Algan, B. (2008) 'The Brand New Version of Article 301 of Turkish Penal Code and the Future of Freedom of Expression Cases in Turkey' German Law Journal, 9 (12): 2237-2252.

${ }^{11}$ After the amendment a permission from the Minister of Justice is required to launch a criminal investigation on the basis of Article 301. According to the figures given in the Progress Report, the Minister of Justice authorized only $8 \%$ of the pending cases referred to him. 
the Commission Article 301 is no longer used systematically to restrict freedom of expression. Apart from this improvement the Commission believes that the Turkish legal framework still fails to provide sufficient guarantees for exercising freedom of expression. On the whole Commission expresses her concern about the increase of open and free debate in Turkish Society (EC Commission, 2009)

\section{Conclusion}

In the first Progress Report the Commission clearly stated that freedom of expression was not fully assured in Turkey. Up until now, the Commission released 12 Progress Reports and stsrting from 2002 Progress Report the critics on the freedom of speech began including progress in the area. At the beginning the main critical areas were Articles 7 and 8 of the Anti-Terror Law, Articles 158, 159, 311 and 312 of the Criminal Code. During this period the new Criminal Code was enacted and related provisions of Anti-Terror Law was amended. The last reports were crtisizing the application of Article 301 of the new Criminal Code, however an amendment was done in 2008 and now the tensions on Article 301 also went down.

In the past years, the situation of journalists, writers and academics constituted an important part in Commission's reports on Turkey's progress towards EU membership. Especially, with the opening up of accession negotiations in 2005, an obvious change in the content and wording of reforms relating to freedom of expression could be observed in progress reports. This includes both legislative changes in the form of amendments and abolishments, and the dimishing number of cases brought gainst persons charged with expressions of non-violent opinions. This does not lead us to the conclusion that Turkey has succeeded to fully comply with the relevant provisions set out by the Copenhagen criteria. The Commission still believes that Turkish Legal framework is still failing to secure the Freedom of Speech and wants new legislative guarantees. More progress is needed so that Turkey becomes eligible for EU membership. This encompasses both further legislative changes and law implementation when dealing with concrete cases. Meanwhile, the Commission urges Turkey to take into consideration both domestic legislation and European Convention on Human Rights in cases brought against freedom of expression. This would enable Turkey to abolish the existing restrictions both in legal and practical terms and fully ensure the freedom of expression. It would also help Turkey to comply with the European norms. 


\section{References:}

Algan, B. (2008). 'The Brand New Version of Article 301 of Turkish Penal Code and the Future of Freedom of Expression Cases in Turkey' German Law Journal, 9 (12)

Baç, M. (2005). 'Turkey's Political Reforms and the Impact of the European Union' South European Society and Politics, 10 (1)

Bıçak, V. (2002). Avrupa İnsan Hakları Mahkemesi Kararlarında İfade Özgürlügü̈. Ankara: Ütopya Basım Yayın Ltd. Şti.

Cini, M. (2003). European Union Politics. Oxford: Oxford University Press.

Craig, P. and Búrca, G. (2003). EU Law: Text, Cases and Materials, Third Edition, Oxford: Oxford University Press.

European Convention on Human Rights: Convention for the Protection of Human Rights and Fundamental Freedoms. Amended Version with Protocol 11, Rome, 1950. Retrieved on 1 June 2009, from: http://www.echr.info.

European Commission. Progress Reports on Turkey, retrieved on 20 October 2009, from: http://ec.europa.eu/ enlargement/candidatecountries/turkey/key_documents_en.htm.

Gunter, M. (2007). 'Turkey's Floundering EU Candidacy and Its Kurdish Problem' Middle East Policy, 14(1)

Hakyemez Y., and Akgün, B. (2002) 'Limitations on the Freedom of Political Parties in Turkey and the Jurisdiction of the European Court of Human Rights' Mediterrenean Politics, 7(2)

Kubicek, P. (2005). 'The European Union and Grassroots Democratization in Turkey', Turkish Studies, 6(3)

Mowbray, A. (2001). Cases and Materials on the European Convention of Human Rights. Edinburgh: Butterwoths.

Özbudun, E. (2007) 'Democratization Reforms in Turkey: 1993-2004' Turkish Studies, 8(2)

Presidency Conclusions of the Helsinki European Council 10/11 December 1999. Retrieved on 1 June 2009 from: http://www.consilium.europa.eu. 
Schimmelfennig, F., Engert, S. and Knobel, H. (2003). 'Costs, Commitment, Compliance: Latvia, Slovakia and Turkey', Journal of Common Market Studies, 41(3)

Single European Act. Retrieved on 1 June 2009, from: http://europa.eu/ scadplus/treaties/singleact_en.htm.

Tezcan, E. (2003). “Türkiye'nin Kopenhag Siyasi Kriterlerine Uyumu Sürecinde Yapılan ve Yapılması Gereken Yasal Değişiklikler Üzerine Bir Değerlendirme" Marmara Journal of European Studies, Vol:11, No:1-2, 2003.

The Constitution of the Republic of Turkey, translated by Erhan Yaşar, retrieved on 1 June 2009 from: http://www.anayasa.gen.tr/1982 Constitution-1995-1.pdf

Treaty of Amsterdam, retrieved on 1 June 2009 from: http://eurlex.europa.eu/en/treaties/dat/1 1997D/htm/ 11997D.html.

Treaty of the European Union. OJ 92/C 191/01, retrieved on 1 June 2009, from: http://europa.eu.int/eur-lex/lex/en/treaties/treaties_founding.htm. 